\title{
Will Congress blot US copybook?
}

\section{Washington}

WHILE the US administration bangs the drum of free trade, Congress is busily preparing to muffle its beat. Now, a coalition of 54 major corporations and association is lobbying hard to persuade Congress not to extend legislation requiring nondramatic works by US authors to be printed in the United States.

The so-called "manufacturing clause" has been declared illegal by the General Agreement on Tariffs and Trade (GATT), and the European Economic Community (EEC) has threatened economic sanctions against the United States if the clause is not allowed to expire at the end of this month. But influential members of Congress want the clause made permanent, and the Senate Finance Committee has approved a bill to do so.

The current manufacturing clause prohibits importing into the United States copyrighted non-dramatic literary material in English unless it is printed and bound there. The effect is to ensure that US copyright material is printed in the United States. The price of books in the United States is consequently estimated to be 12 per cent higher than it would otherwise be. Newspapers are also affected.

Among those most affected by the bill are manufacturers of computers and business equipment; the legislation prevents them from printing instruction manuals and the like abroad, where many of their manufacturing plants are situated. Burroughs, IBM and Xerox are among the corporations that have joined the Coalition to Oppose the Manufacturing Clause. EEC estimates the clause costs it between $\$ 300$ and $\$ 500$ million per year and has threatened retaliatory sanctions.

The clause is also opposed by the US Department of Commerce: commerce secretary Malcolm Baldrige told the Senate Finance Committee last week that the clause is "an embarrassment" that undermines the United States' position as it tries to negotiate fair trade practices and strong protection for intellectual property rights overseas. Baldrige said he would advise President Reagan to veto any legislation Congress might pass to extend the clause.

The clause was formerly set to expire in 1982, but Congress voted then to extend it and overturned a presidential veto. It had not by then been declared illegal by GATT, however, and opponents are using the GATT ruling as a major plank for their case. The clause also makes it impossible for the United States to adhere to the Berne copyright convention, which provides international protection for intellectual property rights.

The controversial clause dates back to 1891 , when it was enacted to protect the
US printing industry. Although it has since been progressively weakened, the printing industry would still like to see the clause extended, and some members of Congress are unwilling to be seen to be increasing foreign competition for the industry. Critics contend, however, that the number of US printing jobs that would be saved if the clause is extended is trivial compared with the number of jobs lost in other export industries. Singapore, thought to be one of several countries that turn a blind eye to piracy of US-copyright trade materials, has tied improvements to its copyright laws to an exemption from the US manufacturing clause, and other countries may follow suit.

Some computer manufacturers have already chosen to forgo US copyright protection on their manuals printed overseas rather than print them in the United States, according to the coalition. Vico Henriques, president of the Computer and Business Equipment Manufacturers' Association, said it was recognized good business practice to print documentation for a product at the point of manufacture so that local alterations and conditions could be included easily.

The legislation approved by the Senate finance committee to extend the clause (S. 1822) would remove the existing exemption for Canada. The exemption allows Canada to export to the United States UScopyright works not printed in the United States. Retaliatory action from Canada would therefore also be on the cards if the legislation were passed.

To placate the opposition, the Senate bill, introducted by Republican Senator Strom Thurmond, includes some compromise provisions. The chief one is that after two years, waivers could be issued allowing imports from countries which the Secretary of Commerce certifies as fair trading partners that respect US copyright laws (among other things). But the US Trade Representative, Clayton Yeutter, told the finance committee that he had "strong doubts that Canada, the European Economic Community or Japan could obtain a waiver" under the "cumbersome" waiver provisions. Yeutter said the ostensible purpose of the clause, protection of US printers' jobs, was unnecessary: total employment in the US printing and publishing sector is projected to grow by 2.2 per cent a year to 1995 , creating more than 30,000 jobs each year.

The House of Representatives' Judiciary Committee is soon to consider a bill identical to Thurmond's. Senate floor action on Thurmond's bill is scheduled for next week; the coalition is only cautiously optistic that it will have rallied sufficient votes to defeat it.
British software

\section{Looking over the shoulder}

THE common British conceit that Britain may not be much good at hardware, but has the edge in software, takes a tumble this week with the publication of a report by a committee of the Advisory Council for Applied Research and Development (ACARD) that cries for urgent action from everybody in sight (Software: $A$ vital key to UK competitiveness, HMSO, $£ 6.00$ ). It is not true, says ACARD, that British software houses run on an inside track; after the United States, France is next, while even in Europe, West Germany is number two.

Both perceptively and courageously, ACARD sees the British software problem as part of the general decline of British industrial competiveness. While the "man in the street" may still expect that software houses would be among the most rapidiy growing and most profitable parts of British industry, the real prospect is quite different.

The committee says that evidence from overseas confirms its own view that the rate of growth of the British software industry will lag behind that of the world leaders, that market shares will decline and that the British market for software will be dominated by overseas suppliers in the 1990s.

The ACARD committee gives several reasons for this gloomy outlook, including the chronic shortage of skilled people in information technology, the failure of companies in the field to spend enough on selling the products they have developed and, latterly, their unwillingness or incapacity to invest in research and development. According to the ACARD report, the chief objective among software houses now is to make software development less labour-intensive, which means investment in the techniques of automation.

The diagnosis is more persuasive than the remedy. Above all, ACARD wants Britain to know there is a problem. Beyond that it has a miscellany of remedies, such as the proposal that government departments should give thought to generic needs when commissioning new developments, that the Science and Engineering Research Council should elevate the information engineering committee of its engineering board to the status of a full board and that the programming language BASIC should be outlawed as soon as it can be replaced by something better.

The committee's theme is that designing a piece of software is like making anything else - a task in engineering in the widest sense. Many British software-users will say amen to that. 